\title{
FOLK CULTURE AS A TOURIST ATTRACTION IN A METROPOLITAN ENVIRONMENT
}

\author{
Veres, Gábor
}

\begin{abstract}
In the development of each destination as a tourist attraction, facilities are of primary importance, and their enhancement, as well as the building of the services and the appearance of the suprastructure are important aspects in most places. Cultural heritage as a tourist attraction is, in most cases, the property of a given region, be it built, intellectual or tangible heritage. The lecture examines how tourism can be an attractive part of the cultural heritage away from its local environment. In this case, folk culture, which successfully contributes to the tourist attraction of big cities. The presentation focuses primarily on European examples where folk culture and the organization, institution or service that represents it are organically integrated into the metropolis. Budapest is a prominent place where an ethnographic showroom was built in the Varosliget at the end of the 19th century and was of great interest. There are, of course, quite different expectations for museums presenting intangible cultural heritage in the 21st century than they were in the 19th. This is also an important issue in the Hungarian capital because the construction of the new Ethnographic Museum in the Varosliget is underway, and its impact on tourism is also expected by professionals. (The first author's research was supported by the grant EFOP-3.6.1-16-2016-00001 "Complex improvement of research capacities and services at Eszterhazy Karoly University”.)
\end{abstract}

Keywords: cultural tourism, tourist attraction cultural heritage, folk culture, ethnographic museum

JEL: Z3

DOI: 10.33032/acr.2020.10.1.181 
Folk tourism is a broadening area of tourism. As a touristic product its central element is some kind of attraction or attractiveness that grabs the attention of tourists and therefore it leads to a demand. In connection with the attractiveness, folk tourism can work the most effectively if it is built on attraction and on the touristic infrastructure making possible its uncovering, marketing. Its role can be intensified on and on if the touristic suprastructure making possible the stay and consumption of the tourist is joined to this also. We can speak about complex cultural touristic product in the case if also in the infrastructional and suprastructional services being in the centre of the product and completing the attraction representing cultural value the culture significantly appears.

It is worth examining how folk culture can become a touristic attraction. Folk tourists pay particular attention on century-old traditions, the cultural inheritance having roots in the past but existing even in these days. Folk culture comprises an inheritance of a highly broader social layer since agricultural production was significant in the Carpathian Basin until the 19th century. Embourgeoisement and industrialisation were processed slowly and later than in Western Europe. The high proportion of society consisted of peasantry working in agriculture. This feature can be an advantage in the cultural tourism for the region today, since a lot more architectural constructions and material or intellectual inheritance have remained from these layers of culture for the 21st century than in Western Europe having had the process of embourgeoisement quickly several centuries ago.

In folk culture, the inheritance of centuries has remained whose existence was provided once in local communities. After the fragmentation of the traditional communities, remembrance, traditionalism and scientific researches also contributed to their subsistence. Today it is attractive for us to have the possibility of „travelling” into the past, the inheritance of former people and community. Wherever they can provide it authentically, folk culture can become a touristic attraction. It is important and favourable by the aspect of tourism that the folk culture is complex and can be found in every area of human life. It can be described as a complexity but also, one or more elements can be emphasized which can be developed as an attraction. Processions connected to important days and showing national costumes are important as well. As for national costumes, this effect can be emphasized by folk dance using folk music of the given area. Folk gastronomy is also popular, whose taste connected to areas, celebrations, weekdays provides a supply almost inexhaustible in which all tourists can find an element attractive for each one of them.

However, the characteristic of folk culture is the limitation of the given area. Several customs of the illustrious days were practised in a wider area the same time, for example the customs of carnival or Pentecost. However, their content shows features connected to specific areas or ethnic groups. And the same for the customs or meals belonging to a given area and not known elsewhere. 
Hungarian tourism had a period before the political changeover when some well-known elements of folk culture were considered as national attraction, national image. That is how German tourists could meet with the wrangler of Hortobágy whipcracking and could taste shepherd meals typical in "the Hungarian desert” formerly. Connecting to touristic attraction, how important question is to be authentic? If a tourist accepts the concept that folk culture is the same in the case of a nation and it has elements developed well-known everywhere, than this question is secondary. In contrary to this, when certain destinations start emphasizing their features - moreover, right because of the competition for tourists' attention - , in the market of touristic attractions of folk culture there appears a really ambiguous picture.

Several studies, researches examined cultural tourists. It is an important statement that in Europe one of the most significant motivations of touristic mobility is the culture, cultural tourists are relatively highly educated and the most of them have a job connected to the cultural sphere. If on the side of demand there are these parameters and characteristics, the supply has to adjust to this since the more educated tourists consider it more important that the attraction of the given area is authentic and typical for that region.

\section{First successes of the folk culture in cities}

The civilian, industrial society of cities is an environment where the appearance of folk culture is thought the furthest. However, the reality is that since the 19th century in several metropolises, especially in the capitals of states people turned towards folk culture. Among the firsts, perhaps we could mention Vienna where there was a world exhibition organized in 1873 . Here rooms and interiors of peasants were presented as well by the exhibitors e.g. Hungary. The exhibition had around a million of attendants. One of its elements - obviously a successful one - was introducing the rural culture. Artus Hazelius (from Sweden) attended the world exhibition as well on who the peasant interiors and the fact that the audience liked them could make an impression. It was Hazelius who created a new type of museum in 1891, namely the open air ethnographic museum. This was called - by the Swedish denomination open air museum. In this, buildings from all around the country were relocated and rearranged typically based on that given region. They chose the capital, Stockholm to establish the new type of the ethnographic show-room.

In Budapest, in the National Exhibition (1885) 15 peasant rooms were introduced, which was accepted with a great interest by the metropolitan audience. These antecedents and those attraction of the visitors and the impression on them highly contributed to 
the fact that folk culture could have an important role in the monumental Millennial National Exhibition (1896, Budapest), too. The pavilion of Ottó Herman presenting ancient professions (fishing, shepherding) had a separate pavilion. Its success could be seen by the fact that these topics - with some additions, making it more spectacular were sent to the world exhibition of Paris four years later.

It was a lot more monumental expediency to build to Millennial Village in the City Park of Budapest in 1896. As a part of the village, they built a church, a tavern and 24 peasant houses based on several areas of the country. The houses reflected also the ethnic relations of Hungary of that time period. In 12 houses they presented the folk culture of Hungarians, in the other 12 houses they presented that of ethnicities living in the country. The exhibition was open between the 2nd of May and the 3rd of November, 1896, and the sources wrote about a million of visitors here, too. In the millennial village folk products were sold as well, in the tavern of Debrecen traditional meals could be tasted. Great events took place also: visitors coming here could participate in Matyó and Bosnian weddings.

It was this exhibition which verified the most that in a metropolitan environment how big interest there exists for the topic and how well folk culture „could be sold”.

Certainly, authenticity was an important question already here, too, it is not accidental that the establishment and the direction of its development were entrusted to the Ethnographic Development of National Museum. In the jubilee exhibition of Vienna, 1898, a Hungarian tavern and Hungarian (folk) gastronomy were appeared.

The above mentioned successes of the 19th century highly contributed to the folk culture becoming a part of the thinking of the touristic supply of cities.

\section{Folk culture in the touristic supply of cities in our days}

The present paper, because of the limits of content, cannot have an aim of completely following and evaluating of the metropolitan presence of folk culture. Hence in the followings, after analysing the earlier examples of recognising touristic possibilities, effects we study the segments appearing in our days. In the cities, so also in Budapest, the highlighted events of the touristic profession are the tourism exhibitions, including a great number of national and foreigner exhibitors. A number of exhibitors draw their future guests with the attraction of folk culture. The visitors attending these exhibitions, mainly arriving from the capital, can feel the strong presence of the folk culture in the touristic supply.

The capital gives place to the introduction of folk creators regularly. In the long weekend of August, the highlight of the touristic period, for myriads visited the Celebration of Trades in Budapest. The touristic and craftsmen fairs strengthen the 
touristic attraction of the city, but at the same time the countryside, the rural tourism also consider it as detached works, a luring. Although these events are returning but we can meet with them in general only occasionally, usually once a year.

However, there are segments where the constant presence of folk culture can be experienced in the cities. Folk culture is a part, a layer of the cultural inheritance so accordingly areas connected to mental, material and built inheritance can be interpreted as well. Besides occasional events, the mental inheritance appears e.g. in the constant supply of institutions providing teaching folk music, folk dance. For example, in the supply of the House of Traditions teaching for example folk dance is provided by age groups. Although in these courses foreigners participate also, because of their long and regular timing primarily people living in Budapest and its neighbourhood can be enlisted.

The presence of folk built inheritance still exists in the cities in our days but its touristic importance is changeable. We can meet such element as well where a building was preserved in its original place from the time when the rural environment was typical instead of the city and the metropolis developed around it only later. An example for this is the Dyckman farm house in New York which is the last peasant house of Manhattan. In 1784, it was in the centre of an agricultural area of hundreds of acres. In contrary to several others, it tided over the centuries and no skyscraper was built in its place. In 1916, a museum was established in the building, and since it is the last memento of a time period, it can be connected well to the package of tourists aiming to get to know New York.

Only a few similarly „lucky” building have remained in the cities, the relocated objects and those groups are said at least such typical. For example, the open air museum of Bukarest (Muzeul Naţional al Satului „Dimitrie Gusti”) opened in 1936. In the communist time period they talked several times about moving it somewhere but it did not happen, luckily. At time moment, the Romanian capital is a highlighted touristic object having more than half million visitors a year.

The material inheritance of the folk culture is a constant element of ethnographic museums in the touristic supply of cities. The Museum of European and Mediterranean Civilization (MuCEM) is an ethnographic museum of high attendance in Europe today. Marseille was the European Capital of Culture in 2013. In Paris before this time period the attendance of the ethnographic museum decreased continuously. Connecting to the ECOC project, this had been the first "national” institution about which they decided to move it from the capital. With a cost of 144.3 million Euro, they planned a new museum building and the topic of the planned permanent exhibition was set to a newer, wider European - Mediterranean context. In Washington, the museums of the Smithsonian Institution are among the most attended public collections of the world, their touristic role is outstanding. By the aspect of our topic, we have to highlight two museums: National Museum 
of African American History \& Culture which was established being encouraged by president Obama in 2016, and the National Museum of the American Indian which opened its doors in 1989 for its visitors. The ethnographic museum of Vienna opened again in 2017 after a 3 year period of reconstruction. It has a new name: Weltmuseum. It gives information about the connection of Austria and other nations of the world, as well. Besides introducing the work of the Austrian scientists studying distant cultures, the Austrian folk art has a significant space, too $(1400 \mathrm{~m} 2)$. In the Ethnographic Museum of Budapest, in the permanent exhibition of the traditional culture of Hungarians we could see the material souvenirs of peasants, in connection with their life styles. Although the exhibition looked back for a past of decades with its outdated installation and presenting methods, it still had a great attendance until its closure in 2017, primarily because of its prominent collection of objects. The museum could give renewable, interesting, spectacular topics to its visitors with its temporary collections.

Examining the concept of attraction and infrastructure, we can often observe overlap. Although in the case of a museum, attendants are drawn primarily by the collections, usually the building functioning as an exhibition room is at least such exciting as the exhibition itself. The means of transport belonging to the dynamic infrastructure make possible primarily the approach of the sights of cultural tourism. For example, by the city buses you can find the main cultural attractions of a destination and their itinerary helps the spatial orientation of tourists since it shows the most important, unmissable sights for them. In the area of travel services there is also a possibility for the culture to be emphasized, for example, by using vehicles having a cultural value. For example, the open air house in Szentendre carried its visitors by special old-timer buses. The aim of suprastructural services is to fulfil the need of accepting guests, giving accommodation to them, providing for them etc. In the area of hospitality connecting to cultural tourism the restaurants, cafes, buffets of the museum have a special property - besides creating income - of partly completing the cultural experience.

A unique example of connecting culture and hospitality is creating menus having cultural feature or denominating some meals specially, even via using a cultural inheritance of a given destination or attraction. In cultural tourism, the secondary touristic suprastructure is constituted by the services of the retail sector, especially the gift shops of cultural institutions e.g. museums. In Budapest, a new building is being built for the material inheritance of folk culture. In the exhibition planned, besides the traditional Hungarian folk culture, there is an increasing aspect system of introducing the connection between the Hungarians and the world, through the work and collections of famous Hungarian travellers, researchers. The young age group gets a particular attention, a special permanent exhibition is created for them, too. Visitors primarily look for experiences and memories, the exhibits themselves do 
not attract everyone. That is why the language, the way of introduction, the system of context and the possibility of enjoyment of the exhibitions are so significant. In connection with the experiences obtained there is an increasing expectation of interactivity, actively involving the consumer into the process of service-transmitting knowledge, entertaining - for example by applying means of modern technology.

\section{References}

[1.] Dávid L. - Bujdosó Z. - Patkós Cs. (2003): A turizmus hatásai és jelentősége a területfejlesztésben. In: A terület-és településfejlesztés alapjai. Szerk. SüliZakar István, Dialóg Campus Tankönyvek, Budapest-Pécs, 433-453. pp

[2.] Jankó J. (1989): A millenniumi falu. Néprajzi Múzeum tudománytörténeti kiadványsorozata. Budapest. 180 p.

[3.] Magyar Turizmus Zrt. kutatási csoport (2009): A Magyar lakosság kulturális turizmussal kapcsolatos ismeretei, attitüdjei és utazási szokásai. In: Turizmus Bulletin 12. 3. 2-19 pp.

[4.] Puczkó L. - Rácz T. (2005): A turizmus hatásai. Aula Kiadó. Budapest 494 p.

[5.] Sulyok J. (2005): Kulturális turizmus az európai városokban. In: Turizmus Bulletin 9. 3. 18-30 pp.

\section{Author:}

\section{Dr Gábor Veres PhD}

associate professor

Eszterházy Károly University

3300 Eger, Eszterházy tér 1

veres.gabor@uni-eszterhazy.hu 